\title{
PROPAGATION ANALYSIS OF PU RADIONUCLIDES AS A RESULT OF FIRE INCIDENTS IN THE EXCLUSION ZONE OF THE CHERNOBYL NPP IN APRIL 2020
}

\author{
Daryna F. Kozhevnikova*, (D) Volodymyr V. Levenets \\ NSC "Kharkiv Institute of Physics \& Technology" NASU \\ 1, Academichna str., 61108, Kharkiv, Ukraine \\ *Corresponding Author: marko@kipt.kharkov.ua \\ Received March 7, 2021; revised April 7, 2021; accepted April 15, 2021
}

In consequence of nuclear accidents that have occurred in various parts of the world, radioactive contamination of the environment is observed. The risks of spreading pollution can increase during floods, fires and some natural disasters. The lack of effective measures that aimed at eliminating possible sources of fire in the meadow zone and forest lands in the Chernobyl exclusion zone (ChEZ) leads to a high risk of fire emergence. The temporal and spatial distribution of fires shows that they occur throughout the ChEZ, including in the most contaminated areas. The risk of fires increases with climate change and measures to prevent them should be considered in emergency programs. ChEZ area is contaminated with long-lived radionuclides such as ${ }^{137} \mathrm{Cs},{ }^{90} \mathrm{Sr}, \mathrm{Pu}$ isotopes $\left({ }^{238} \mathrm{Pu},{ }^{239+}{ }^{240} \mathrm{Pu},{ }^{241} \mathrm{Pu}\right)$ and ${ }^{241} \mathrm{Am}$. As a result of forest fires radionuclides contained in wood and underlying surface are carried out into the atmosphere along with smoke. Diseases arising under the influence of ionizing radiation from $\mathrm{Pu}$ and ${ }^{241} \mathrm{Am}$ isotopes pose a serious problem for human health. To assess of the spatial distribution of Pu isotopes and ${ }^{241} \mathrm{Am}$ we used data on forest fires that occurred in the Chernobyl zone in April 2020. To evaluate the dynamics of the release of radioactive substances into the atmosphere during fire incidents on the ChEZ territory, the following software products were used: NASA WorldView, HYSPLIT program. The HYSPLIT program allows to reconstruct the trajectories of radionuclide propagation in the atmosphere using meteorological data and to obtain a reliable picture of the distribution of radionuclides in the study area. The maps of the volumetric activity of Pu isotopes in the air and the fallout on the soil as a result of fires were obtained. It was found that the radioactivity due to the presence of this element in the air and during the fallout of radioactive particles on the soil is low (it reaches $1.0 \mathrm{E}-7 \ldots 0.1 \mathrm{~Bq} / \mathrm{m}^{3}$ in the air, $1.0 \mathrm{E}-6 \ldots 1 \mathrm{~Bq} / \mathrm{m}^{2}$ on the soil). The analysis of the propagation of $\mathrm{Pu}$ isotopes as a result of the movement of air masses in the places of fires in the exclusion zone of the Chernobyl nuclear power plant and the associated dangers for the population and the environment has been carried out.

KEYWORDS: Chernobyl NPP, Pu isotopes and ${ }^{241} \mathrm{Am}$, release of radioactive substances, fire zone, distribution of radionuclides.

The spring floods of the Pripyat River and forest fires are two of the most important factors contributing to the migration of radionuclides from the ChEZ. The lack of effective measures aimed at eliminating possible sources of fire during the time after the Chernobyl accident has led to a high risk of the occurrence and spread of fires in the ChEZ zone, which includes 260,000 hectares of forests and meadows. This area is heavily contaminated with long-lived radionuclides such as ${ }^{137} \mathrm{Cs},{ }^{90} \mathrm{Sr}, \mathrm{Pu}\left({ }^{238} \mathrm{Pu},{ }^{239+240} \mathrm{Pu},{ }^{241} \mathrm{Pu}\right)$ and ${ }^{241} \mathrm{Am}[1]$.

Since nuclear radiation slows down the rate of decomposition of inert organic materials, the amount of dead wood, ground layers of dried leaves and twigs in forest lands increases and the risk of fire increases. Forest fires that took place in the ChEZ, for example, in 1992, covered an area of 17,000 hectares, and revealed the presence of sources of ignition throughout the entire area, including in the areas most contaminated with radionuclides [2].

Fire prevention and suppression activities pose a serious health hazard to firefighters, who can reach the annual individual dose limit in a relatively small number of days.

Now the main threat to the population and the environment in the ChEZ is caused by fires in places where plants grow that have accumulated radionuclides as a result of the migration of radioactive particles from the soil cover. The degree of public exposure associated with the burning of radioactive wood and grass depends on the distribution of contamination in the combustion material, the amount of contaminated combustible material and the type of fire.

The accumulation of each radioactive element is special for different plant species. Currently from 70 to $85 \%$ of radionuclides are concentrated in the upper soil layers of forests and meadows, as well as in the layer of organic residues on the soil surface in forests and mosses, and from 15 to $30 \%$ are deposited on trees (bark, needles, wood and branches) or grass. The mass of dead wood in the ChEZ, contaminated with radioactivity, is estimated at $1.4 \cdot 10^{6} \mathrm{~m}^{3}$, which may lead to further growth of forest fires. According to forecasts [2], the amount of contaminated dead wood in the ChEZ will be $2.4 \cdot 10^{6} \mathrm{~m}^{3}$ in 2020 .

Forests most at risk of fire are concentrated in the central and northern parts of the ChEZ and include the most contaminated areas in the west and northeast of the ChNPP.

The temporal and spatial distribution of fires shows that they occur throughout the ChEZ, including in the most contaminated areas, within a radius of $10 \mathrm{~km}$ from the Chernobyl nuclear power plant, where there is the highest activity level for the isotopes ${ }^{137} \mathrm{Cs},{ }^{90} \mathrm{Sr}, \mathrm{Pu}$ and ${ }^{241} \mathrm{Am}$. It is also obvious that in the north and north-east of this zone, fires regularly cross the border between Ukraine and Belarus. Fires become more frequent in the spring. The highest risk of fires is observed in July and August.

As a result of forest fires in ChEZ, radionuclides contained in wood and underlying surface are carried out into the atmosphere along with smoke. The transport of ${ }^{90} \mathrm{Sr},{ }^{137} \mathrm{Cs}$ and $\mathrm{Pu}$ isotopes during fires occurs in the form of smoke (C) M. F. Kozhevnikova, V. V. Levenets, 2021 
particles and mineral dust. Dust particles, from 2 to 100 microns in diameter, are deposited again near the source. Small particles of two types, ranging in size from 0.04 to 0.07 microns and from 0.1 to 0.3 microns, are carried over considerable distances and may have a negative effect on humans if inhaled.

The data of the automatic radiation monitoring system under the control of the State Ecological Center show a pronounced increase in the volumetric activity of radionuclides in the air of the ChEZ during large fires. Individual radionuclides can migrate more than $100 \mathrm{~km}$ from the fire zone, thereby exposing the population to a dose of radiation above the permissible limit.

The aim of this work is to assess the risks of the spread of $\mathrm{Pu}$ and ${ }^{241} \mathrm{Am}$ radionuclides in the ChEZ and beyond, as a result of fires in places where plants grow and accumulate dead wood with a high level of radioactive contamination by these isotopes. It is supposed to assess the risk of radioactive impact on the population and the environment associated with this process and to determine possible ways to reduce the negative consequences.

\section{SUBJECT OF STUDY AND INPUT DATA}

The explosion of the Chernobyl nuclear power plant reactor in 1986 caused the release of about $12,000 \mathrm{PBq}$ of radioactive material into the atmosphere. At present, the radioactive contamination of the soil is determined by the presence of isotopes ${ }^{137} \mathrm{Cs},{ }^{90} \mathrm{Sr},{ }^{238,239,240,241} \mathrm{Pu},{ }^{241} \mathrm{Am}$. The bulk of these radionuclides during the release was part of the particles of irradiated nuclear fuel (the fuel component of the Chernobyl radioactive fallout) [3].

In this regard, the maps of the density of contamination with these radionuclides for the territory of the near zone of the Chernobyl NPP are similar (Fig.1 and Fig.2).

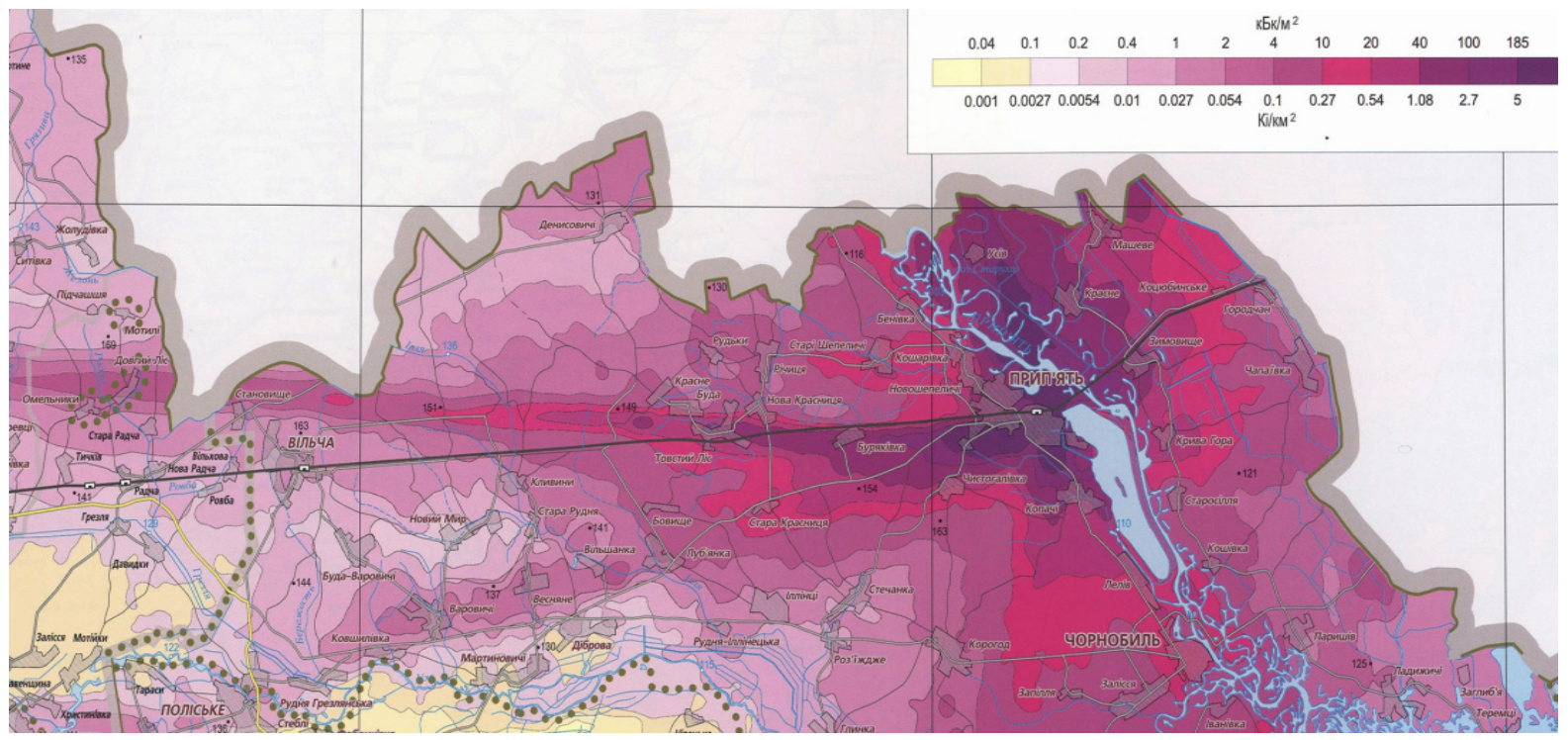

Figure 1. Total contamination of the ChEZ surface with Pu isotopes [4]

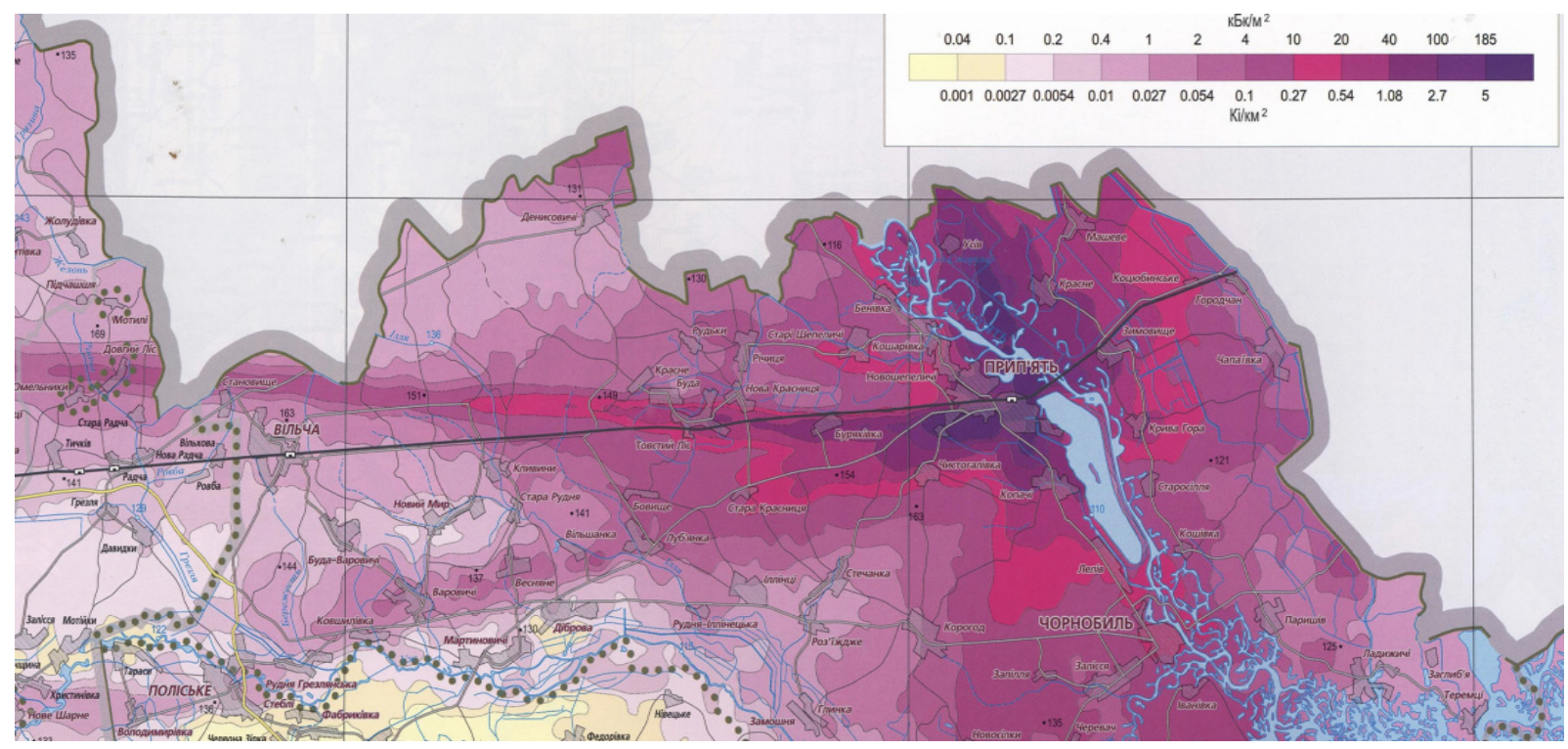

Figure 2. Total surface contamination $\mathrm{ChZO}^{241} \mathrm{Am}[4]$ 
The zone within a radius of $10 \mathrm{~km}$ directly around the Chernobyl nuclear power plant is heavily contaminated with $\mathrm{Pu}$ and ${ }^{241} \mathrm{Am}$ isotopes. Figures 1 and 2 show the total contamination of the ChEZ surface with $\mathrm{Pu}$ and ${ }^{241} \mathrm{Am}$ isotopes, respectively [4].

The decay of $\beta$-emitting ${ }^{241} \mathrm{Pu} \quad\left(\mathrm{T}_{1 / 2}=14.4\right.$ years $)$ gives rise to long-lived $\alpha$-radionuclides ${ }^{241} \mathrm{Am}$ $\left(\mathrm{T}_{1 / 2}=4.32 \cdot 10^{2}\right.$ years $)$ and ${ }^{237} \mathrm{~Np}\left(\mathrm{~T}_{1 / 2}=2.14 \cdot 10^{6}\right.$ years $)$, which have a high radio toxicity. Calculations have shown that by now about $90 \%$ of the ${ }^{241} \mathrm{Pu}$ isotope has already decayed and turned into ${ }^{241} \mathrm{Am}$. Unlike ${ }^{241} \mathrm{Pu},{ }^{241} \mathrm{Am}$ compounds have a higher solubility and, therefore, a higher migration capacity [5].

Diseases arising under the influence of ionizing radiation from $\mathrm{Pu}$ and ${ }^{241} \mathrm{Am}$ isotopes pose a serious problem for human health.

Possible routes of $\mathrm{Pu}$ and ${ }^{241} \mathrm{Am}$ entering the human body: as a result of inhalation, during food intake, through the skin. Lifetime carcinogenic risk factors were calculated for almost all radionuclides, including isotopes of $\mathrm{Pu}$ and ${ }^{241} \mathrm{Am}$ (Table 1). Food intake is usually the most common type of exposure. However, the risk coefficient for this route of intake is much lower than for inhalation [6].

To assess the spatial distribution of $\mathrm{Pu}$ isotopes and ${ }^{241} \mathrm{Am}$, we used data on forest fires that occurred in the Chernobyl zone in April 2020 [7]. In this work, the electronic Atlas of Ukraine was used to assess the density of radioactive contamination in the areas of combustion. Radioactive contamination with recalculation of activity of $\mathrm{Pu}$ isotopes in soil for 2020 [4].

Table 1. Radiological risk factors

\begin{tabular}{|c|c|c|}
\hline \multirow{2}{*}{ Isotope } & \multicolumn{2}{|c|}{ Lifetime carcinogenic risk } \\
\cline { 2 - 3 } & Inhalation $\left(\mathrm{pCi}^{-1}\right)$ & Ingestion $\left(\mathrm{pCi}^{-1}\right)$ \\
\hline${ }^{241} \mathrm{Am}$ & $2.4 \times 10^{-8}$ & $9.5 \times 10^{-11}$ \\
\hline${ }^{241} \mathrm{Pu}$ & $2.8 \times 10^{-10}$ & $1.9 \times 10^{-12}$ \\
\hline${ }^{238} \mathrm{Pu}$ & $3.0 \times 10^{-8}$ & $1.3 \times 10^{-10}$ \\
\hline${ }^{239} \mathrm{Pu}$ & $2.9 \times 10^{-8}$ & $1.3 \times 10^{-10}$ \\
\hline${ }^{240} \mathrm{Pu}$ & $2.9 \times 10^{-8}$ & $1.3 \times 10^{-10}$ \\
\hline
\end{tabular}

The areas of fire burnout were taken into account for two main categories of landscapes: forest and meadows. The forest category included all areas covered with woody vegetation (coniferous and deciduous), and the category of meadows also included drained areas covered with reeds, which, as a rule, became the primary source of fire development. The areas of water bodies, roads and other man-made unnatural objects were not taken into account for calculating the areas of fire.

\section{SPATIAL ANALYSIS METHODS}

To assess the dynamics of the release of radioactive substances into the atmosphere during fire incidents on the ChEZ territory, the following software products were used: NASA WorldView, HYSPLIT program [8], data on radioactive contamination of territories [4,9]. To identify fire incidents and estimate their parameters in the Worldview tool the MODIS Fire and Thermal Anomalies product was used, which operates with data from the Terra (MOD14) and Aqua (MYD14) satellites, as well as the combined Terra and Aqua satellite product (MCD14).

The HYSPLIT program allows to reconstruct the trajectories of radionuclide propagation in the atmosphere using meteorological data and to obtain a reliable picture of the distribution of radionuclides in the study area. The basic model simulation input parameters are: starting time (year, month, day, hour); location (starting locations, as latitude, longitude, and height); start time and duration of the dispersion (i.e., run-time); pollutant characteristics (number of pollutant species, emission rates, emission duration).

The input meteorological data necessary for HYSPLIT-4 were taken from the meteorological model calculations based on in-situ measurement results.

\section{RESULTS OF THE RESEARCH}

Forest fires broke out in an area heavily contaminated in 1986 during the Chernobyl accident. These fires reached the ChEZ and the area around the NPP on April 8, 2020 (Fig. 3). According to some estimates, the area of fire reached 20,000 hectares [10].

The total area of fires on the territory of the ChEZ around the Chernobyl NPP and in the adjacent territories of the Polessky district of the Kiev region, as well as in the Ovruch district of the Zhytomyr region for the period from 2 to 20 April was determined at $870 \mathrm{~km}^{2}$. Of these, about $445 \mathrm{~km}^{2}$ are combustion zones in a fire in the Ovruch district of the Zhytomyr region; $340 \mathrm{~km}^{2}$ is the area of the territories burned out during the period of the fire in the Polessky district (the main part on the territory of the ChEZ). In the exclusion zone around the Chernobyl nuclear power plant, about $65 \mathrm{~km}^{2}$ burned out, as well as about $20 \mathrm{~km}^{2}$ on the left bank of the Pripyat river [7]. 
The total takeaway of $\mathrm{Pu}$ isotopes in the smoke fraction, which could be transferred to a long distance outside the burnout zones during fires, is $59 \mathrm{MBq}$ (of which from fires in the Polessky district of ChEZ and adjacent territories about $25 \mathrm{MBq}$ and from fires in the area of Chistogalovka village and cooling pond of the ChNPP (CP ChNPP) in ChZO about $19 \mathrm{MBq}$ ) [7].

Figure 3 shows a summary map of the fires detected from the satellite in the period from 2 to 20 April, 2020. On April 8, the fire incidents began in several points of the Ovruch district of the Zhytomyr region. They are not related to the primary source of fires in the exclusion zone, but the north-western wind caused dispersion of the combustion products contaminated with ${ }^{137} \mathrm{Cs}$ in the direction of Kiev, therefore the radiological situation in Kiev for April 8 was formed under the influence of sources of fire formation mainly outside the ChEZ.

In the period from April 8 to April 10 in Kiev the highest levels of ${ }^{137} \mathrm{Cs}$ activity in aerosols were observed for the period of fire formation (according to the UkrGMI and CGO (Central Geophysical Observatory)). The data in the range from 0.2 to $0.6 \mathrm{mBq} / \mathrm{m}^{3}$. Background volumetric activities were observed in almost 100 times lower [7]. During the period of fire formation, according to observations in Kiev, the averaged volumetric activity of ${ }^{137} \mathrm{Cs}$ in the air did not exceed $1 \mathrm{mBq} / \mathrm{m}^{3}$.

On April 8 hotbeds of fire also developed directly in the exclusion zone (Fig. 4).

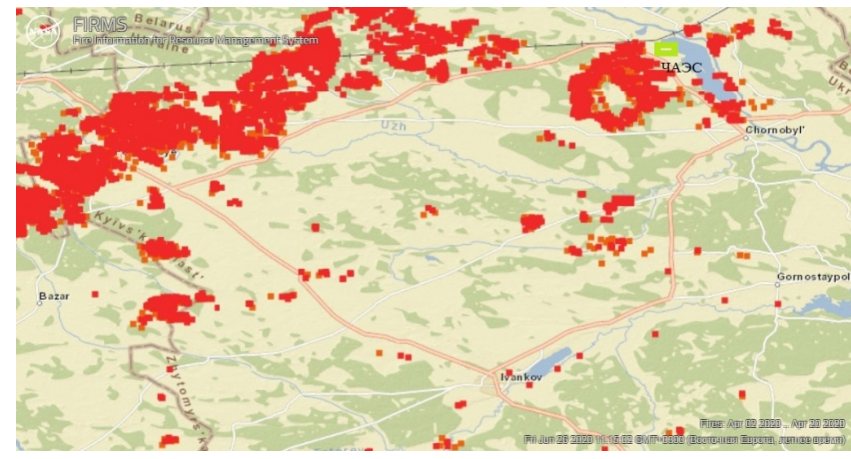

Figure 3. A summary map of the fires detected from the satellite in the period from 2 to 20 April 2020 .

The fire zone is highlighted in red

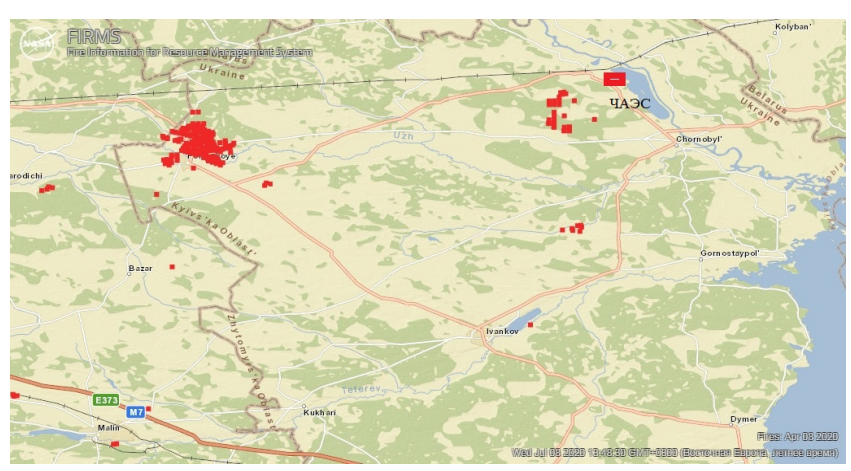

Figure 4. Map of fire sites on April 8, 2020. The fire zone is highlighted in red

To study the spatial distribution of $\mathrm{Pu}$ isotopes, the period from 8 to 13 April 2020 was chosen. At this time, the largest removal of radionuclides from the ChEZ territory was observed. For calculations, a source height of $20 \mathrm{~m}$ was chosen, and the removal duration was 24 hours.

Figure 5 shows the dynamics of the activity removal of radionuclides in radioactive aerosols from a fire during this period in the area of Kopachi village - Chistogalovka village - CP ChNPP [7]. The largest removal of Pu isotopes from fires occurred on April 9 and April 13, 2020.

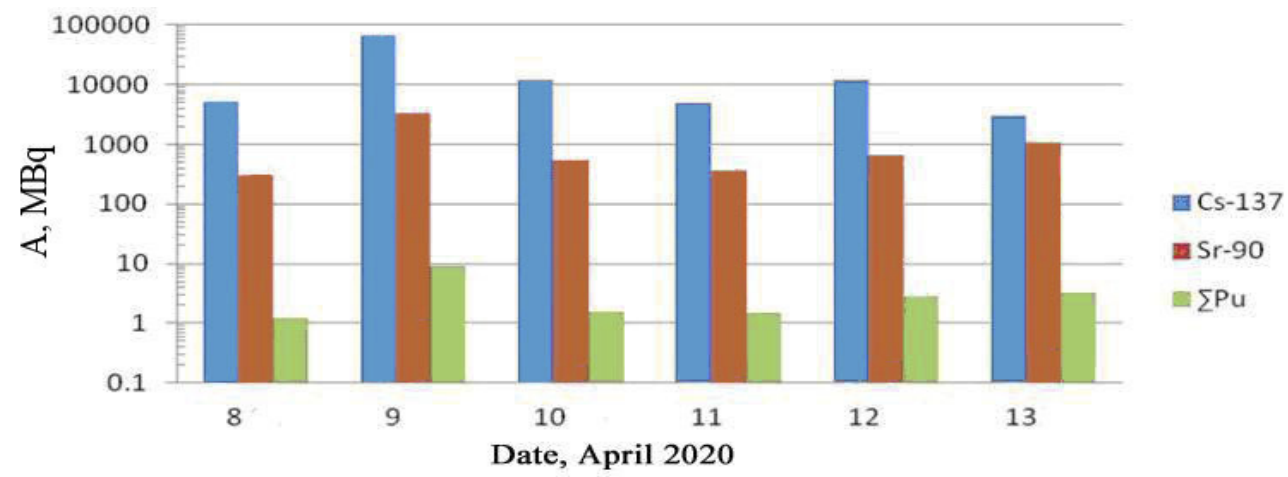

Figure 5. Dynamics of the activity removal of radionuclides in radioactive aerosols from a fire in period from April 8 to April 13, 2020 in the area Kopachi village - Chistogalovka village - CP ChNPP

To analyze the propagation of $\mathrm{Pu}$ isotopes as a result of fires on the territory of the ChEZ the maps of the volumetric activity of radionuclides in the air and during fallout on the soil in the period from April 8 to April 13, 2020 were constructed.

Figure 6 shows a map of the volumetric activity of $\mathrm{Pu}$ radionuclides in the air on April 9, 2020 from a fire in the area of Kopachi village - Chistogalovka village. The wind changes direction from the northwest, which led to the transfer of combustion products towards Kiev - to the west. Accordingly, the main centers of fires expanded eastward, and the zones of ignition in the near $10 \mathrm{~km}$ zone around the Chernobyl NPP also expanded. In particular, a fire in the area of the source of the initial ignition (in the Polessky district) begins to spread eastward (the area of combustion was about $21 \mathrm{~km}^{2}$ ) [7]. 

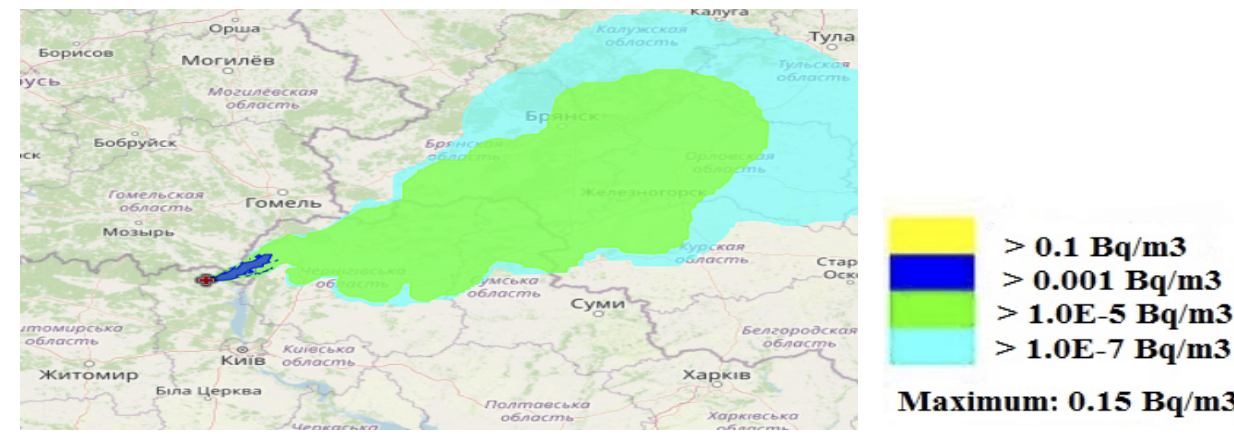

Figure 6. The volumetric activity of Pu isotopes in the air on April 9, 2020

from a fire in the area with Kopachi village - Chistogalovka village (for 24 hours), the source height is $20 \mathrm{~m}$

Figure 7 shows a map of the surface activity of Pu isotopes during the fallout on the soil on April 9, 2020.
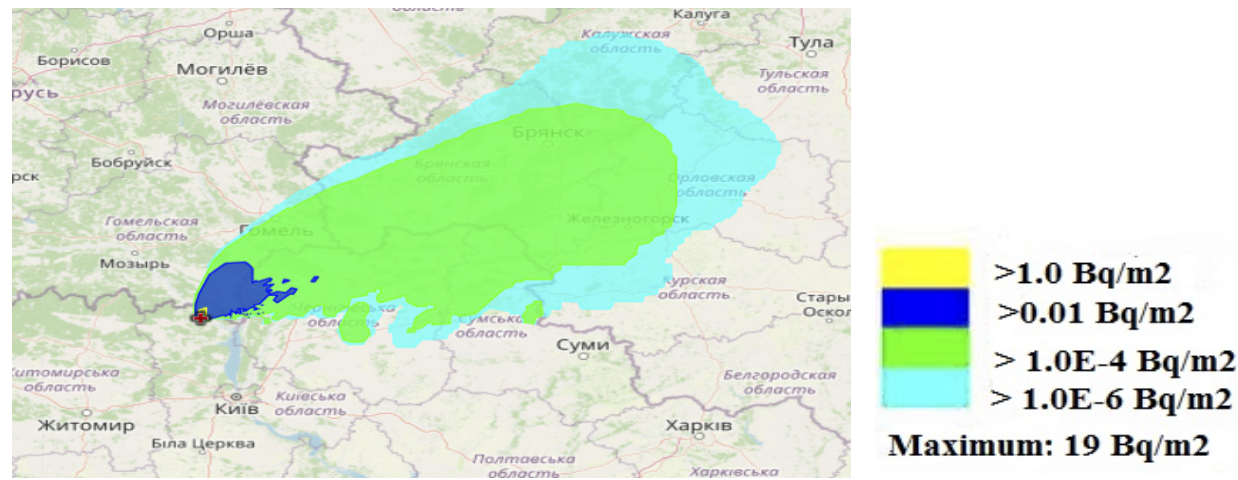

Maximum: $19 \mathrm{~Bq} / \mathrm{m} 2$

Figure 7. The surface activity of $\mathrm{Pu}$ isotopes during deposition on the soil on April 9, 2020 from a fire in the area with Kopachi village - Chistogalovka village (for 24 hours), the source height is $20 \mathrm{~m}$

Figure 8 shows a map of the volumetric activity of Pu isotopes in the air on April 13, 2020 from a fire in the area with Kopachi village - Chistogalovka village.
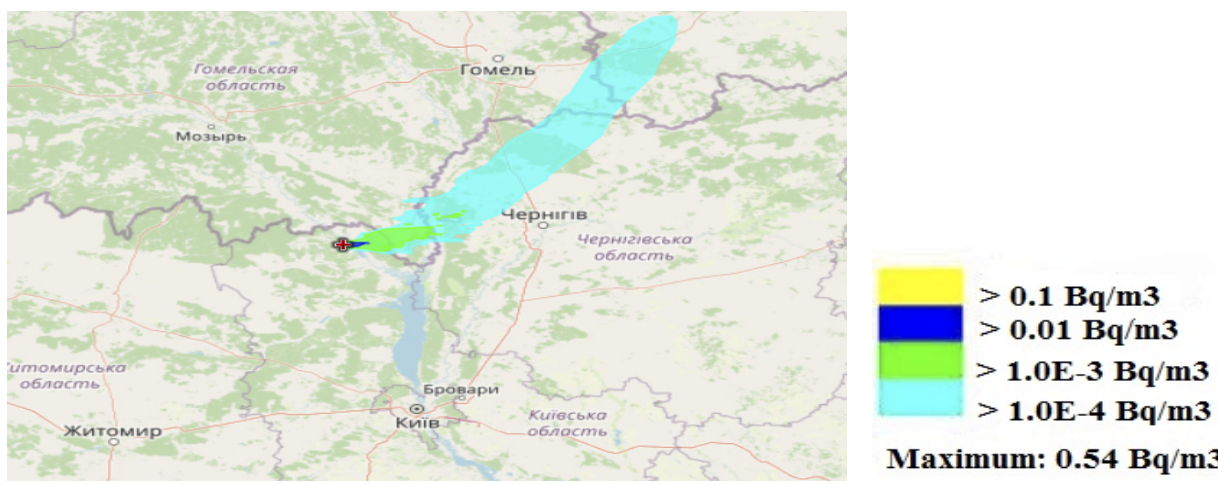

Figure 8. The volumetric activity of Pu isotopes in the air on April 13, 2020

from a fire in the area with Kopachi village - Chistogalovka village (for 24 hours), the source height is $20 \mathrm{~m}$

The combustion centers in the Polessky district spread in the northeastern direction and crossed the zone of the location of the so-called fuel trace of radioactive fallouts of 1986 year. The area of combustion was about $18 \mathrm{~km}^{2}$. The combustion on the territory of the Red Forest covered $3.5 \mathrm{~km}^{2}$. The wind had a northeasterly direction, so the territory of Ukraine, Belarus and Russia was subjected to Pu pollution. Figure 9 shows a map of the surface activity of $\mathrm{Pu}$ isotopes during the fallout on the soil on April 13, 2020.

On the fuel traces of the Chernobyl radioactive fallout due to the radioactive decay of ${ }^{241} \mathrm{Pu}$, the accumulation and increase in the activity of ${ }^{241} \mathrm{Am}$ occurs over time. The maximum activity of ${ }^{241} \mathrm{Am}$ will be reached approximately 70 years after the Chernobyl accident, by 2056 , while the activity of ${ }^{241} \mathrm{Am}$ will be no more than $20 \%$ higher than the level as of 2017-2018 (Table 2). During the increase in the activity of ${ }^{241} \mathrm{Am}$ (about 50 years), the activity of long-lived ${ }^{239} \mathrm{Pu}$ $\left(T_{1 / 2}=24100\right.$ years $)$ and ${ }^{240} \mathrm{Pu}\left(\mathrm{T}_{1 / 2}=6563\right.$ years $)$ will practically not change, while the activity of ${ }^{238} \mathrm{Pu}\left(\mathrm{T}_{1 / 2}=87.74\right.$ years) due to its radioactive decay, it will decrease by $40 \%$. As a result, the total activity of $\alpha$-emitting radionuclides will slightly increase over the next 50 years, and then monotonously decrease.

At the same time, the maximum of the total activity of $\alpha$-emitting radionuclides will exceed the level as of $2017-18$ by only $6 \%$. With equal dose coefficients per unit of inhalation intake activity for alpha emitting radioisotopes 
$\mathrm{Pu}$ and ${ }^{241} \mathrm{Am}$ (Table 2), such a slight change in their activity over the next 50 years will not have a significant effect on the value of conservative estimates of inhalation doses for personnel and for the population [11].
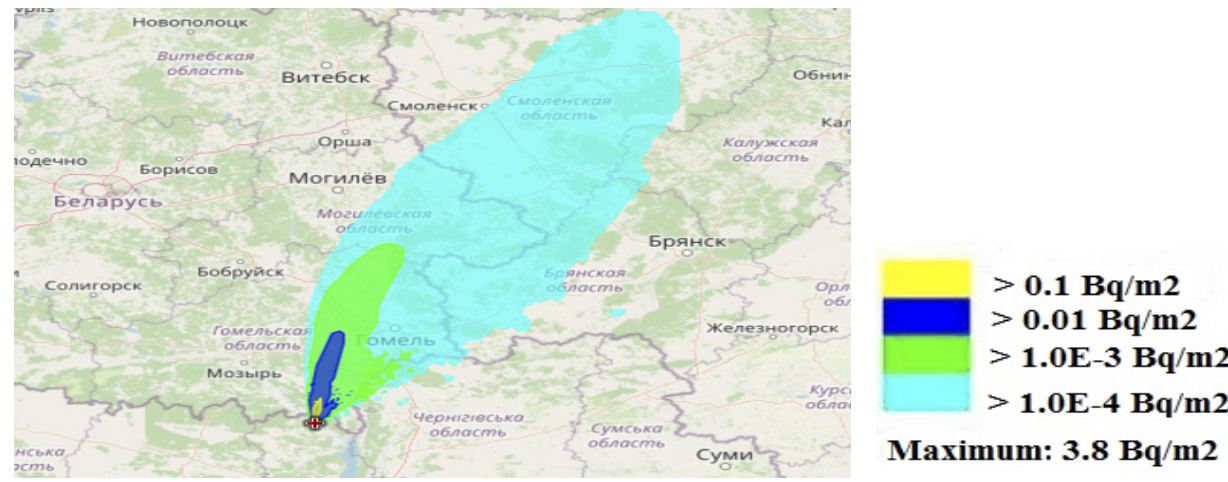

Figure 9. The surface activity of $\mathrm{Pu}$ isotopes during the fallout on the soil on April 13, 2020

from a fire in the area with Kopachi village - Chistogalovka village (for 24 hours), the source height is $20 \mathrm{~m}$

Since an increase in the activity of ${ }^{241} \mathrm{Am}$ by $20 \%$ in the next 50 years (Table 2 ) will not have a significant effect on the change in the formation of inhalation doses of internal and external irradiation of personnel and the environment in the $\mathrm{ChEZ}$, no significant changes in approaches to control the spread of ${ }^{241} \mathrm{Am}$ are required. However, since there is evidence of a significantly higher assimilability of ${ }^{241} \mathrm{Am}$ by meadow vegetation compared to ${ }^{239}, 240 \mathrm{Pu}$ [12], over time the problem of the spread of this nuclide along with combustion products or through the food chain can create additional risks for the environment and humans. Therefore, permanent tracking of ${ }^{241} \mathrm{Am}$ migration is an important link in the creation of a comprehensive system for monitoring radiation contamination of territories and predicting negative consequences for the population.

Table 2. [10] Dynamics of changes in the specific activity of $\alpha$-emitting radionuclides in the fuel component of Chernobyl radioactive fallout, $\mathrm{Bq} / \mathrm{g}$

\begin{tabular}{|c|c|c|c|c|c|c|c|c|c|}
\hline \multirow{2}{*}{ Radionuclides } & \multicolumn{9}{|c|}{ Year } \\
\cline { 2 - 11 } & 2017 & 2021 & 2026 & 2031 & 2036 & 2046 & 2056 & 2076 & 2186 \\
\hline${ }^{238} \mathrm{Pu}$ & $6.3 \mathrm{E}+6$ & $6.1 \mathrm{E}+6$ & $5.8 \mathrm{E}+6$ & $5.6 \mathrm{E}+6$ & $5.4 \mathrm{E}+6$ & $5.0 \mathrm{E}+6$ & $4.6 \mathrm{E}+6$ & $3.9 \mathrm{E}+6$ & $3.6 \mathrm{E}+6$ \\
\hline${ }^{239} \mathrm{Pu}$ & $5.1 \mathrm{E}+6$ & $5.1 \mathrm{E}+6$ & $5.1 \mathrm{E}+6$ & $5.1 \mathrm{E}+6$ & $5.1 \mathrm{E}+6$ & $5.1 \mathrm{E}+6$ & $5.1 \mathrm{E}+6$ & $5.1 \mathrm{E}+6$ & $5.1 \mathrm{E}+6$ \\
\hline${ }^{240} \mathrm{Pu}$ & $7.8 \mathrm{E}+6$ & $7.8 \mathrm{E}+6$ & $7.8 \mathrm{E}+6$ & $7.8 \mathrm{E}+6$ & $7.8 \mathrm{E}+6$ & $7.8 \mathrm{E}+6$ & $7.7 \mathrm{E}+6$ & $7.7 \mathrm{E}+6$ & $7.7 \mathrm{E}+6$ \\
\hline${ }^{241} \mathrm{Am}$ & $2.5 \mathrm{E}+7$ & $2.6 \mathrm{E}+7$ & $2.8 \mathrm{E}+7$ & $2.8 \mathrm{E}+7$ & $2.9 \mathrm{E}+7$ & $3.0 \mathrm{E}+7$ & $3.0 \mathrm{E}+7$ & $3.0 \mathrm{E}+7$ & $2.9 \mathrm{E}+7$ \\
\hline$\Sigma$ & $4.4 \mathrm{E}+7$ & $4.5 \mathrm{E}+7$ & $4.6 \mathrm{E}+7$ & $4.7 \mathrm{E}+7$ & $4.7 \mathrm{E}+7$ & $4.7 \mathrm{E}+7$ & $4.7 \mathrm{E}+7$ & $4.6 \mathrm{E}+7$ & $4.6 \mathrm{E}+7$ \\
\hline
\end{tabular}

The long-lived $\mathrm{Pu}$ radionuclides fell out in the composition of fuel particles with a high specific mass. Therefore, they did not spread over long distances, and the density of soil surface contamination, according to preliminary data, exceeded the limits established for them practically only within the boundaries of the $30-\mathrm{km}$ exclusion zone. Pu is characterized by a very low ability to penetrate biological membranes. Therefore, the coefficients of its accumulation by plants from the soil and entering the human body are several orders of magnitude lower than for $\mathrm{Sr}$ and $\mathrm{Cs}$ [1]. $\mathrm{Pu}$ isotopes are present in forest organic matter in insignificant amounts and remain fixed in the mineral fraction of soil contaminated in 1986. Thus, its re-transport during fires in the ChEZ is low.

\section{CONCLUSIONS}

The maps of the volumetric activity of $\mathrm{Pu}$ isotopes in the air and the fallout on the soil as a result of fires in April 2020 were obtained. As a result of the distribution analysis of $\mathrm{Pu}$ radionuclides in the territory under consideration, it was found that the radioactivity due to the presence of this element in the air and during the fallout of radioactive particles on the soil is low (it reaches $1.0 \mathrm{E}-7 \ldots 0.1 \mathrm{~Bq} / \mathrm{m}^{3}$ in the air, $1.0 \mathrm{E}-6 \ldots 1 \mathrm{~Bq} / \mathrm{m}^{2}$ on the soil). Despite the high radiotoxicity of $\mathrm{Pu}$ isotopes, the contribution from the resulting radioactivity to the radiation exposure of the population through inhalation or consumption of food will be insignificant.

The risk of fires in the ChEZ increases with climate change and measures to prevent them should be considered in emergency programs.

This information will provide important insight into the dynamics of accumulation, transformation, and migration of $\mathrm{Pu}$ and ${ }^{241} \mathrm{Am}$ isotopes. And also to study the impact of ionizing radiation from fires in the ChEZ on the environment. 


\section{ORCID IDs}

(D)Maryna F. Kozhevnikova, https://orcid.org/0000-0003-2464-3847

(DVolodymyr V. Levenets, https://orcid.org/0000-0002-6439-0576

\section{REFERENCES}

[1] B.S. Prister, A.A. Klyuchnikov, V.G. Baryakhtar, V.M. Shestopalov, and V.P. Kukhar, Проблемы безопасности атомной энергетики. Уроки Чернобыля [Nuclear power safety problems. Lessons from Chernobyl], (NAS of Ukraine, Institute of NPP safety problems, Kyiv, 2016), pp. 356. (in Russian)

[2] S.V. Zibtsev, J.G. Goldammer, S. Robinson, and O.A. Borsuk, Unasylva, 243/244(66), 40-51 (2015), http://www.fao.org/3/I4447E/i4447e.pdf.

[3] V. Kashparov, S. Levchuk, M. Zhurba, V. Protsak, Yu. Khomutinin, N.A. Beresford, and J.S. Chaplow, ESSD, 10, 339-353 (2018), https://doi.org/10.5194/essd-10-339-2018.

[4] L.Ya. Tabachny, and etc, Атлас Україна. Радіоактивне забруднення [Atlas Ukraine. Radioactive interference], (TOV "Intellectual Systems GEO", 2008), pp. 52. (in Ukrainian)

[5] M.F. Kozhevnikova, V.V. Levenets, I.L. Rolik, and A.A. Shchur, PAST, 3(109), 26-30 (2017), https://vant.kipt.kharkov.ua/ARTICLE/VANT_2017_3/article_2017_3_26.pdf. (in Russian)

[6] J. Peterson, M. MacDonell, L. Haroun, and F. Monette, Radiological and Chemical Fact Sheets to Support Health Risk Analyzes for Contaminated Areas, (Argonne National Laboratory Environmental Science Division, 2007), pp. 133, https://www.philrutherford.com/Radiation_Links/ANL_ContaminantFactSheets_All_070418.pdf.

[7] V. Protsak, O. Voitsekhovych, and G. Laptev. Estimation of radioactive source term dynamics for atmospheric transport during wildfires in Chernobyl zone in spring 2020. (Ukrainian Hydrometeorological Institute, Kiev, 2020). https://uhmi.org.ua/msg /fire2020/analytical.pdf. (in Ukrainian)

[8] R.R. Draxler, and G.D. Hess, Description of the HYSPLIT-4 Modeling System. Silver Spring: Air resources Laboratory, NOAA Technical Memorandum ERL ARL-224. pp. 22. (1997), https://www.arl.noaa.gov/documents/reports/arl-224.pdf

[9] M. De Cort, Y.S. Tsaturov, Directorate-General for Research and Innovation (European Commission), European Commission, Atlas of cesium deposition on Europe after the Chernobyl accident, (Office for Official Publications of the European Communities, Luxembourg, 1998), pp. 63, https://op.europa.eu/s/oXu8

[10] Information note $\mathrm{n}^{\circ} 5$, (IRSN, 2019), pp. 11, https://www.irsn.fr/EN/newsroom/News/Documents/IRSN_InformationReport_Fires-in-Ukraine-in-the-Exclusion-Zone-around-chernobyl-NPP_05052020.pdf

[11] Assessment of the distribution of radionuclides and the impact of industrial facilities in the Chernobyl exclusion zone (Final Report). INRIR, 2018, 217 p. http://chornobyl-gef.com/wp-content/uploads/2018/05/Assesment-of-Distr.-Radioact.pdf

[12] O.A. Shurankova, and V.P. Kudryashov, Problems of health and ecology, 1(7), 67-71 (2006), https://elib.gsmu.by/handle/GomSMU/1075. (in Russian)

\section{АНАЛІЗ ПОШИРЕННЯ РАДІОНУКЛІДІВ РU В РЕЗУЛЬТАТІ ПОЖЕЖ У КВІТНІ 2020 р В 30 ВІДЧУЖЕННЯ ЧОРНОБИЛЬСЬКОЇ АЕС \\ М.Ф. Кожевнікова, В.В. Левенець}

Начіональний науковий центр «Харківський фізико-технічний інститут», НАНУ вул. Академічна, 1, 61108, Харків, Україна

Внаслідок ядерних аварій, що сталися в різних частинах світу, спостерігається радіоактивне забруднення навколишнього середовища. Ризики поширення забруднення можуть зростати під час повені, пожеж та деяких стихійних лих. Відсутність ефективних заходів, спрямованих на ліквідацію можливих джерел пожежі в луговій зоні та лісових угіддях у зоні відчуження Чорнобиля (ЧЗВ), призводить до високого ризику виникнення пожежі. Часовий та просторовий розподіл пожеж свідчить про те, що вони трапляються на всій території ЧЗВ, у тому числі в найбільш забруднених районах. Ризик пожеж зростає зі зміною клімату, і заходи щодо їх запобігання слід враховувати в надзвичайних програмах. Територія ЧЗВ забруднена довгоживучими радіонуклідами, такими як ${ }^{137} \mathrm{Cs},{ }^{90} \mathrm{Sr}$, ізотопи $\mathrm{Pu}\left({ }^{238} \mathrm{Pu},{ }^{239+}{ }^{240} \mathrm{Pu},{ }^{241} \mathrm{Pu}\right)$ та ${ }^{241} \mathrm{Am}$. В результаті лісових пожеж радіонукліди, що містяться в деревині та підстильній поверхні, потрапляють в атмосферу разом 3 димом. Хвороби, що виникають під впливом іонізуючого випромінювання ізотопів $\mathrm{Pu}$ та ${ }^{241} \mathrm{Am}$, становлять серйозну проблему для здоров'я людини. Для оцінки просторового розподілу ізотопів $\mathrm{Pu}$ та ${ }^{241} \mathrm{Am}$ було використано дані про лісові пожежі, які сталися в Чорнобильській зоні в квітні 2020 р. Для оцінки динаміки викидів радіоактивних речовин в атмосферу під час пожеж на території ЧЗВ, використовувались програмні продукти: NASA WorldView, програма HYSPLIT. Програма HYSPLIT дозволяє за допомогою метеорологічних даних реконструювати траєкторії поширення радіонуклідів в атмосфері та отримати достовірну картину розподілу радіонуклідів на досліджуваній території. Отримано карти об'ємної активності ізотопів Рu в повітрі та випадінь на грунті в результаті пожеж. Встановлено, що обумовлена присутністю цього елемента радіоактивність в повітрі та при випаданні радіоактивних частинок на грунт невисока (досягає в повітрі $1.0 \mathrm{E}-7 \ldots 0.1$ Бк/м³

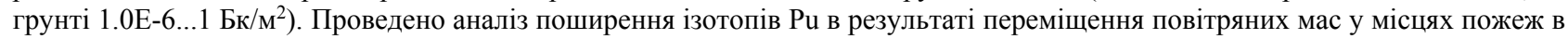
зоні відчуження Чорнобильської АЕС та пов'язаних з цим небезпек для населення та навколишнього середовища.

КЛЮЧОВІ СЛОВА: Чорнобильська $\mathrm{AEC}$, ізотопи $\mathrm{Pu}$ та ${ }^{241} \mathrm{Am}$, викид радіоактивних речовин, зона пожежі, розподіл радіонуклідів. 